\title{
Regulatory Affair Documentation
}

National Cancer Institute

\section{Source}

National Cancer Institute. Regulatory Affair Documentation. NCI Thesaurus. Code C115723.

Records pertaining to a trial's compliance with government laws and regulations. 